\title{
CHEMICAL COMPOSTION OF TAURUS FIR (Abies cilicica subsp. isaurica) OLEORESIN ${ }^{1}$
}

\author{
Ayben Kilic Pekgözlü̈ ${ }^{*}$ and Esra Ceylan²
}

\footnotetext{
${ }^{1}$ Received on 25.05.2017 accepted for publication on 03.04.2018.

${ }^{2}$ University of Bartin, Department of Wood Science \& Engineering, Bartin, Turkey. E-mail: <akilic@bartin.edu.tr>and <eguner@bartin.edu.tr>.

*Corresponding author.
}

\begin{abstract}
The main objective of this study was to determine the chemical composition of both turpintine and colophony parts of Abies cilicica subsp. isaurica (Taurus fir) oleoresin collected from Mersin-Turkey. Colophony of taurus fir was not performed before. Hydro-distillation was applied for the separation of turpentine and colophony. Samples were analyzed separately by FID-GC and GC-MS. The yield of oleoresin was 14,3 $\%$ turpentine and $82,5 \%$ colophony. Fourty-six compounds were found in the turpentine where $\alpha$ - pinene $(81,2 \%)$ was the major compound with $\beta$ - pinene $(12,6 \%)$. However, in the colophony abietane type resin acids were forming the main group (abietic 46,8\%, neoabietic 29,5\%). Resin hydrocarbons and terpenes were identified in the unsaponified fraction of colophony of Taurus fir. High $\alpha$ - pinene and abietic acid contents make this oleoresin to be used in pharmacy and chemical industries.
\end{abstract}

Keywords: Turpintine; Colophony; Resin acids..

\section{COMPOSIÇÃO QUÍMICA DO ABETO TAURUS (Abies cilicica subsp. Isauricus) OLEORESINA}

\begin{abstract}
RESUMO - O objetivo principal deste estudo foi determinar a composição química das partes de turpintina e colofonia de Abies cilicica subsp. oleasina de isaurica (Taurus fir) coletada de Mersin-Turkey. A colofonia de taurus fir não foi realizada antes. Utilizou-se hidro-destilação para a separação da terebentina e da colofonia. As amostras foram analisadas separadamente pelo FID-GC e GC-MS. O rendimento de oleorresina foi de $14,3 \%$ de trepentina e $82,5 \%$ de colofonia. Quarenta e seis compostos foram encontrados na terebintina onde o $\alpha$-pineno $(81,2 \%)$ foi o principal composto com $\beta$-pineno $(12,6 \%)$. No entanto, na resina de colifonia, os ácidos de resina formaram o grupo principal (abietic 46\%, neoabietic 29,5\%). Os hidrocarbonetos de resina e os terpenos foram identificados na fração não apontada da colofonia do abeto Taurus. Os altos níveis de $\alpha$-pineno e ácido abítico tornam esta oleorresina a ser utilizada em farmácias e indústrias químicas.

Palavras-Chave: Terebintina; Colofonia; Ácidos resínicos.
\end{abstract}




\section{INTRODUCTION}

Negative effects of synthetic compounds increased the interest of people back to natural products like oleoresin, a natural product obtained from trees. It is composed of turpentine (also called wood turpentine and spirit of turpentine), which is a clear liquid with a pungent odor and bitter taste, and a colophony (rosin) a transparent and brittle part with an aromatic odor. Turpentine consists of mono- and/or sesquiterpenes and attribute as essential oil. Although with time usage areas of turpentine have changed, it is still important for the chemical industry. In the past, it was a solvent in paints and nowadays most popular usage areas are as a raw material in synthesizing flavor and fragrance chemicals, converting $\alpha$ and $\beta$-pinene to synthetic pine oil which is used in solvents, deodorants, bactericides, textile industry and mineral flotation (Satil et al., 2011; Rodrigues-Corrêa et al., 2013). Other areas are production of polyterpene resins used in pressuresensitive adhesives, insecticides, dry cleaning and paper sizing. Colophony contains resin acids and nonacidic compounds. It is used in many areas like wise paint, varnish, as a binder in adhesive; in rubber as a plasticizer; as a paper chemical; emulsifier in soft drinks and as a glazing agent in medicine and chewing gum. Derivatives of colophony are used in cosmetics and dental varnishes (Yadav et al., 2016). Also, musicians and baseball pitchers uses colophony (Spinella et al., 2017). China, Brazil, Indonesia, Portugal are the big gum rosin producers (Karlberg, 2012, Serin Odabas et al., 2014). Turkey is also exporting oleoresin in the form of turpentine and colophony.

Abies cilicica is one of the native fir species in Turkey with two subspecies A.cilicia subsp.isaurica (resinous buds and glabrous young shoots) and A.cilicia subsp.cilicica (non-resinous buds and hairy young shoots) (Akkemik and Oral, 2011). The cones of fir species, which has an axis and a scale, fall in autumn when they reach to maturity. Local people collect oleoresin from these fallen scales for their traditional usage and to sell it to pharmacy firms. Ethanol extract of resin has high antioxidant and antimicrobial activity (Yavaser et al., 2015). Chemical composition of essential oil obtained from cone has been investigated and wound healing and anti-inflammatory activity was found (Tumen et al., 2011). Also phenolic and lipophilic constituents of cones were analyzed (Kilic et al., 2011, 2013). The goal of this study was to analyze the chemical composition of Taurus fir oleoresin. Colophony of Taurus fir was analyzed for the first time. Colophony is an biodegradable polymer and is promising in the drug industry as an emulsifying, taste masking, microencapsulating, binding and matrix-forming agent (Yadav et al., 2016).

\section{MATERIALS AND METHODS}

\subsection{Material}

The oleoresin of Taurus fir (Abies cilicica subsp. isaurica) was collected from Vayvayli village of Erdemli in the province of Mersin-Turkey in December-January 2015 at the altitude of 1400-1700. In the fir trees, oleoresin occures naturally on stem and cones. It can be collected directly with hand from the stem or the one which falls from cones with the effect of wind from the ground. Generally, local people collect the oleoresin in autum or winter time after it falls. In this study, approximately $1 \mathrm{~kg}$ of oleoresin was collected from fir forest from the ground and stored in a refrigerater till the analysis. Voucher specimen of the fir species kept in the department of Heribarium of Bartin Forestry Faculty, Turkey and identified by Assoc. Prof. Dr. Z. Kaya.

\subsection{Method}

Impurity (bark, dust, insect etc.) affects the quality of the resin. $2 \mathrm{~g}$ oleoresin sample was washed with $100 \mathrm{~mL}$ diethyl ether in tared crucible and dried at $103^{\circ} \mathrm{C}$ to constant weight to determine the impurity. Water content and acid number of oleoresin were determined according to ASTM D 803-65/1970. Extraction of turpentine and colophony from the oleoresin was performed by hydro-distillation in a Clevenger apparatus. $20 \mathrm{~g}$ oleoresin was distilled with $200 \mathrm{~mL}$ distilled water for 4 hour. After the extraction, the liquid part (turpentine) was diluted 1:25 with diethyl ether for the analyses of volatile compounds and solid part (colophony) was fractionated with $0.5 \mathrm{~N} \mathrm{KOH}$ for saponified and unsaponified compounds. $1 \mathrm{~g}$ of colophony treated with $4 \mathrm{~mL} \mathrm{KOH}$ for $3.5 \mathrm{~h}$ at $70^{\circ} \mathrm{C}$. After this process, the sample was taken to a separation funnel and same amount of water was added before washing with petroleum ether $(3 \times 25 \mathrm{~mL})$. Both saponified and unsaponified samples were silylated with $175 \mu$ l Pyridine:BSTFA:TMCS (1:5:1) before the identification.

Revista Árvore. 2018;42(1):e420115

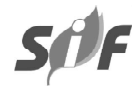


A qualitative analysis was performed by Shimadzu GCMS-QP2010 equipped with TRB-5MS capillary column (30m x $0.25 \mathrm{~mm}$ internal diameter, $0.25 \mu \mathrm{m}$ film thickness); carrier gas was He at flow rate of $0.8 \mathrm{~mL} / \mathrm{min}$; ionization energy was $70 \mathrm{eV}$. For volatile compounds in turpentine, temperature program was $60^{\circ} \mathrm{C}(5 \mathrm{~min})$ raised at $2^{\circ} \mathrm{C} /$ min. to $260^{\circ} \mathrm{C}\left(10 \mathrm{~min}\right.$.) injection temperature was $250^{\circ} \mathrm{C}$ and ion source temperature was $200^{\circ} \mathrm{C} .1 \mu 1$ sample was injected (split ratio 1:50). For saponifiable / unsaponifiable compounds in colophony, temperature program was $120^{\circ} \mathrm{C}$ raised at $6^{\circ} \mathrm{C} / \mathrm{min}$. to $310^{\circ} \mathrm{C}$. Injection temperature was $260^{\circ} \mathrm{C}$. Components were identified by comparing their mass spectra from commercial libraries (FFNSC, NIST27, NIST147, WILEY 7) and also comparing retention index values of components with literature data (Adams, 2009). The quantitative data was obtained with Shimadzu GC-2010 FID-GC equipped with the same column under the same conditions. Three injections were done for each sample and mean values were used in the table. Supelco C7C30 n-alkane mixture was used for the calculation of Kovats retention indices (RI).

\section{RESULTS}

The water content, acid number and the impurity of oleoresin were determined as $1.2 \%, 116.4$ and $1.98 \%$ respectively. The impurity value was found high and the acid number was low. The reason of high impurity values was because the oleoresin samples were collected from the ground.

The yield of oleoresin was determined after the hydro distillation as $14.3 \%$ turpentine and $82.5 \%$ colophony. Turpentine was analyzed directly with FIDGC and GC-MS. The results are given in Table 1. Fourtysix compounds were determined. The amount of nonidentified was only $0.53 \%$. Monoterpene hydrocarbons $(97.6 \%)$ was the main group follow up with MT-alcohols (1.68\%), MT-ketones (0.18\%), MT-aldehyde (0.18\%), MT-ester $(0.03 \%)$ and sesquiterpene hydrocarbons $(0.07 \%)$. $\alpha$-pinene was found to be the major compound in the turpentine followed by $\beta$-pinene (Fig. 1). Beside these two main compounds sabinene, limonene and myrcene which are known to have antimicrobial and antifungal effects were also seen in the composition. $\beta$-Bourbonene, alloaromadendrene and $\gamma$-cadinene are the only sesquiterpene hydrocarbons determined in the turpentine structure.
Table 1 - Chemical composition of Taurus fir turpentine (\%). Tabela 1-Composição química de Touro para terebintina (\%).

\begin{tabular}{|c|c|c|c|c|c|}
\hline No & Compound & $R I^{a}$ & $\mathrm{RI}^{\mathrm{b}}$ & Amount & Id \\
\hline 1 & Tricyclene & 921 & 916 & $0,10 \pm 0,03$ & $\overline{M S, R I}$ \\
\hline 2 & $\alpha$-Thujene & 924 & 922 & $0,16 \pm 0,04$ & MS,RI \\
\hline 3 & $\alpha$-Pinene & 932 & 935 & $81,2 \pm 1,61$ & MS,RI \\
\hline 4 & Camphene & 946 & 942 & $0,62 \pm 0,02$ & MS,RI \\
\hline 5 & $\begin{array}{l}\text { Thuja-2,4(10)- } \\
\text { diene }\end{array}$ & 953 & 947 & $0,20 \pm 0,03$ & MS,RI \\
\hline 6 & Sabinene & 969 & 967 & $0,76 \pm 0,05$ & MS,RI \\
\hline 7 & $\beta$-Pinene & 974 & 973 & $12,6 \pm 0,45$ & MS,RI \\
\hline 8 & Myrcene & 988 & 987 & $0,53 \pm 0,12$ & MS,RI \\
\hline 9 & $\alpha$-Phellenderen & 1002 & 1001 & $0,07 \pm 0,01$ & MS,RI \\
\hline 10 & $\Delta^{3}$-Carene & 1008 & 1006 & $0,02 \pm 0,0$ & MS,RI \\
\hline 11 & $\alpha$-Terpinene & 1014 & 1011 & $0,05 \pm 0,01$ & MS,RI \\
\hline 12 & p-Menth-1-ene & 1021 & 1016 & $0,05 \pm 0,0$ & MS,RI \\
\hline 13 & p-Cymene & 1020 & 1019 & $0,13 \pm 0,04$ & MS,RI \\
\hline 14 & D-Limonen & 1024 & 1023 & $0,70 \pm 0,06$ & MS,RI \\
\hline 15 & 1,8-Cineol & 1026 & 1024 & $0,09 \pm 0,04$ & MS,RI \\
\hline 16 & E- $\beta$-Ocimene & 1032 & 1033 & $0,02 \pm 0,0$ & MS,RI \\
\hline 17 & Z- $\beta$-Ocimene & 1044 & 1042 & $0,01 \pm 0,0$ & MS,RI \\
\hline 18 & $\gamma$-Terpinene & 1054 & 1052 & $0,08 \pm 0,01$ & MS,RI \\
\hline 19 & cis-Sabinenehydrate & 1065 & 1064 & $0,01 \pm 0,01$ & MS,RI \\
\hline 20 & Terpinolene & 1086 & 1082 & $0,22 \pm 0,03$ & MS,RI \\
\hline 21 & p-Cymenene & 1189 & 1085 & $0,02 \pm 0,02$ & MS,RI \\
\hline 22 & Linalool & 1095 & 1096 & $0,04 \pm 0,0$ & MS,RI \\
\hline 23 & Perillene & 1102 & 1100 & $0,01 \pm 0,0$ & MS,RI \\
\hline 24 & $\begin{array}{l}\text { trans-p-Menth- } \\
2 \text {-en-1-o }\end{array}$ & $\begin{array}{c}1119 \\
1\end{array}$ & 1115 & $0,01 \pm 0,05$ & MS,RI \\
\hline 25 & $\alpha$-Campholenal & 1122 & 1119 & $0,12 \pm 0,05$ & MS,RI \\
\hline 26 & trans-pinocarveol & 1135 & 1129 & $0,26 \pm 0,03$ & MS,RI \\
\hline 27 & $\begin{array}{l}\text { z-Verbenol + } \\
\text { Camphor }\end{array}$ & 1137 & 1133 & $0,13 \pm 0,06$ & MS,RI \\
\hline 28 & E-Verbenol & 1140 & 1137 & $0,21 \pm 0,01$ & MS,RI \\
\hline 29 & Sabina ketone & 1154 & 1147 & $0,04 \pm 0,0$ & MS,RI \\
\hline 30 & Trans-3-Pinanone & 1158 & 1151 & $0,02 \pm 0,0$ & MS,RI \\
\hline 31 & Pinocarvone & 1160 & 1153 & $0,01 \pm 0,05$ & MS,RI \\
\hline 32 & Borneol & 1165 & 1156 & $0,07 \pm 0,20$ & MS,RI \\
\hline 33 & $\begin{array}{l}\text { p-Mentha-1,5- } \\
\text { dien-8-ol }\end{array}$ & 1166 & 1159 & $0,25 \pm 0,07$ & MS,RI \\
\hline 34 & Pinocampheol & 1166 & 1164 & $0,05 \pm 0,06$ & MS,RI \\
\hline 35 & Terpinen-4-ol & 1174 & 1168 & $0,07 \pm 0,02$ & MS,RI \\
\hline 36 & p-Cymene-8-ol & 1179 & 1176 & $0,08 \pm 0,06$ & MS,RI \\
\hline 37 & $\alpha$-Terpineol & 1186 & 1182 & $0,09 \pm 0,01$ & MS,RI \\
\hline 38 & Myrtenal & 1195 & 1186 & $0,06 \pm 0,08$ & MS,RI \\
\hline 39 & Myrtenol & 1194 & 1189 & $0,12 \pm 0,05$ & MS,RI \\
\hline 40 & Verbenone & 1204 & 1201 & $0,11 \pm 0,03$ & MS,RI \\
\hline 41 & E-Carveol & 1215 & 1213 & $0,02 \pm 0,02$ & MS,RI \\
\hline 42 & Nerol & 1127 & 1224 & $0,03 \pm 0,02$ & MS,RI \\
\hline 43 & Bornylacetate & 1284 & 1279 & $0,03 \pm 0,01$ & MS,RI \\
\hline 44 & $\beta$-Bourbonene & 1387 & 1390 & $0,02 \pm 0,01$ & MS,RI \\
\hline 45 & Alloaromadendrene & 1439 & 1417 & $0,01 \pm 0,04$ & MS,RI \\
\hline 46 & $\delta$-Cadinene & 1522 & 1524 & $0,04 \pm 0,26$ & MS,RI \\
\hline \multicolumn{3}{|c|}{$\Sigma$ identified } & \multicolumn{3}{|c|}{99,34} \\
\hline \multicolumn{2}{|c|}{$\sum \mathrm{n} . \mathrm{i}$} & & \multicolumn{3}{|c|}{0,53} \\
\hline
\end{tabular}

Revista Árvore. 2018;42(1):e420115 


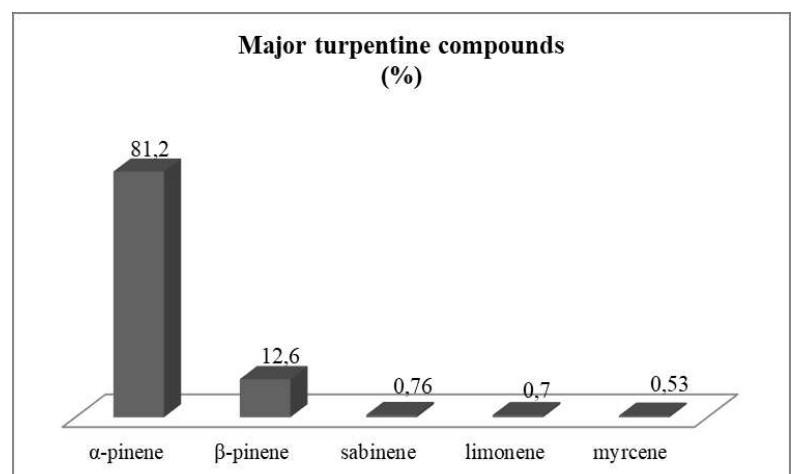

Figure 1 - Major turpentine compounds of Taurus fir (\%). Figura 1 - Principais compostos de terebentina do abeto Taurus (\%).

The amount of acids in the colophony after the saponification is summarized in Figure 2. Abietane is the main acid group which is composed of abietic 46,8 $\%$, neoabietic $29,5 \%$, levopimaric $4,95 \%$, dehydroabietic $4,12 \%$ and palustric $2,38 \%$ acids. Pimarane type of acids (Sandracopimaric and isopimaric) was only $2.5 \%$. The other compounds were hydroxyresin $1,80 \%$ and 1 methyloestra-1,3,5 810-trien-18-nor-17-ketone (3,20\%).

The chromatogram and the amount of unsaponified compounds (neutrals) are shown in Figure 3 and Figure 4. Abieta-8(14),9(11),12-triene is the main compound followed by cycloisolongifolen,9,10-dehydro, neoabietic acid and methyl neoabietate. Unfortunately, 3,80\% pimaric acid was determined in the unsaponified fraction. The amount of total non-identified compounds were $6,20 \%$.

\section{DISCUSSION}

Appropriate value of impurity in various oleoresin samples are between $0.08-0.98 \%$ and acid number 90 -

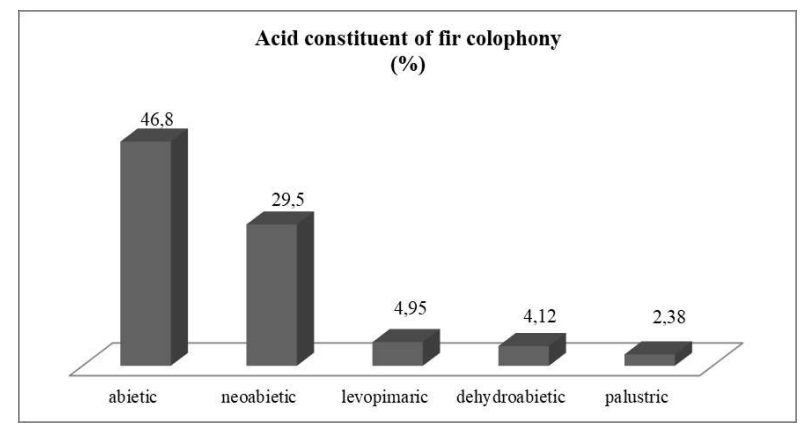

Figure 2 - Acid constituents of Taurus fir colophony (\%). Figura 2-Componentes ácidos de colofonia de abeto Taurus (\%).

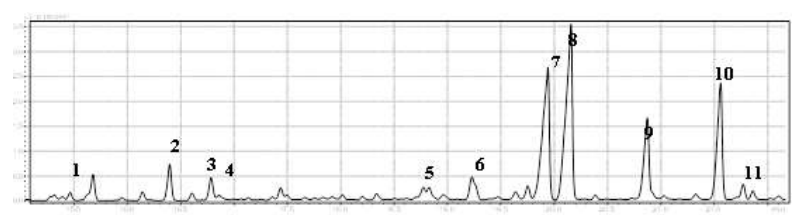

Figure 3 -FID-GC chromatograms of unsaponifiable constituents of Taurus fir colophony. 1:abieta-8,11,13-triene18-al; 2: kaur-16-ene; 3:m-Anisic acid; 4:1phenanthrene carboxylic acid; 5: kaura-5,16-dien18-ol; 6:pimaric acid; 7 :cycloisolongifolen, 9,10 dehydro;8:abieta-8( 14$), 9\left(\begin{array}{ll}1 & 1\end{array}\right), 12$ triene,9:Methylneoabietate; 10:neoabietic acid; 11: retinol acetate.

Figura 3 - Cromatogramas de FID-GC de constituintes insaponificáveis de colofonia de touro-abeto. 1 : abieta-8,11,13-trieno-18-al; 2: kaur-16-ene; 3: ácido m-anisico; Ácido 4: 1-fenantren-carboxílico; 5: kaura-5,16-dien-18-ol; 6: ácido pimarico; 7: ciclooisolongifoleno, 9, 10-desidro; 8: abieta-8 (14), 9(11), 12-trieno, 9: Metilenoabietate; 10: ácido neoabietic; 11: acetato de retinol.

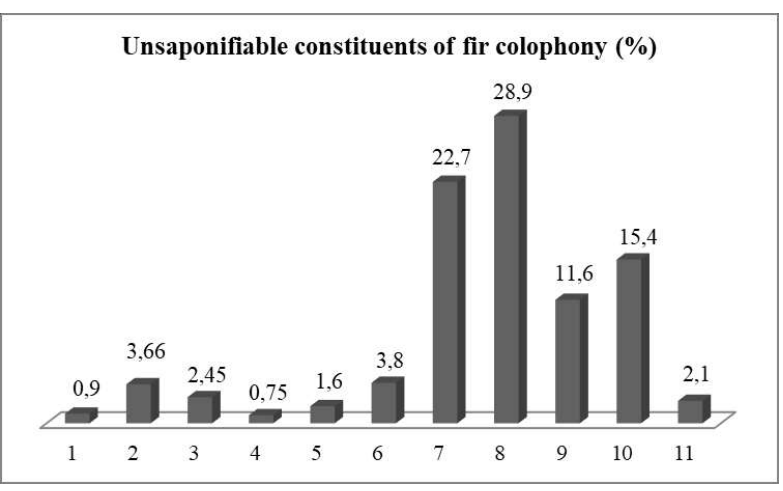

Figure 4-Unsaponifiable constituents of Taurus fir colophony $(\%)$. Notification of the bars are the same as in Figure 3.

Figura 4-Constituintes insaponificáveis da colofonia de touro-abeto (\%). A notificação das barras éa mesma que na Figura 3.

144.7 (Hafizoglu and Deniz, 2010). Comparing with these findings, our impurity value was high and acid number is low. As mentioned above, the samples were collected from ground in the autumn. These two reasons affected the impurity and the acid number. Instead of collecting from the ground and waiting for autumn, it could be more effective to pick up samples directly from the trees and store in suitable conditions. The water content in P.brutia oleoresin was found to be between 0.062\% (Deniz, 1987) and, according to Turkish Standards, the water content in oleoresin must be below 7\%. Our result was appropriate with these findings.

Revista Árvore. 2018;42(1):e420115 
There are some factors affecting the chemical composition of turpentine such as tree species and age, geographic location and isolation process (Silvestre and Gandini, 2008; Goren et al., 2010, Rogachev and Salakhutdinov, 2015). Unsaturated hydrocarbon monoterpenes like $\alpha$-pinene and $\beta$-pinene are found to be the significant compounds. The results are in agreement with literature (Dayisoylu and Alma, 2009). Today, mostly turpentine is used in synthetic pine oil production which is utilized in veterinary and general medicinal applications. Also, synthetic pine oil is used in household cleaning and disinfection products (Hofer, 2015). Limonene, camphene and $\alpha$-terpinene, the other important compounds, are used in flavor - fragrance and pharmaceutical industries (Nuttens et al., 2015).

A big part of oleoresin was found to be the colophony (82\%). Although the composition of colophony changes according to the species and production method; $90 \%$ percent is resin acids and 10\% neutral components (Karlberg, 2012). Abietic acid and dehydroabietic acid are the major acids as also seen in our results. It is known that abietic acid has a lipoxygenase activity, possessed anti-inflammatory properties and binds to phospholipids bilayer (Yadav et al., 2016). Also, it has a positive effect on the acoustic properties of violens (Spinella et al., 2017). As abietic acid itself is known to be non-allergenic or weak allergen, some of the oxidation products such as 7-oxodehydroabietic acid have major contact allergens. By autoxidation, abietic acid can easily be oxidized even during storage of test-trays. Hydroxyresin $(1,8 \%)$ are formed in this way. In order to improve the technical properties of colophony, abietic acid and its isomers are modified. Both modified and unmodified colophony are used in various areas (Karlberg, 2000; Nilsson et al., 2009; Kim et al., 2017; Gether et al., 2017).

\section{CONCLUSION}

Oleoresin composition of Taurus fir consist of $14.3 \%$ turpentine and $85.5 \%$ colophony with $81.2 \%$ $\alpha$-pinene and $12.6 \% \beta$-pinene in turpentine and 46.8 $\%$ abietic acid in colophony. With this composition, both turpentine and colophony can be utilized in various areas such as pharmacy because of its high $\alpha$-pinene content. Also, colophony can be used in chemical and cosmetic industry for its abietane type acids.

However, collection method of this product must be revised. Collecting it from the ground caused high impurity and oxidation. Instead of waiting oleoresin to drop from cones to ground in autum or winter time, matured cones before falling can be collected directly.

\section{REFERENCES}

Adams RP. Identification of essential oil components by gas chromatography/mass spectroscopy. $4^{\text {th }}$ ed. Carol Stream: Allured Publishing; 2009.

Akkemik Ü, Oral D. Abies Mill 1754. In: Yaltirik F, Akkemik Ü. editors. Türkiye'nin Doðal Gymnospermleri (Açýk Tohumlular). Ankara: Orman Genel Müdürlüðü Yayinlari 214 s; 2011. p.19-39. (em turco)

Dayisoylu SK, Alma MH. Chemical analysis of essential oils from cones rosin of Cilician fir (Abies cilicica subsp.cilicica). African Journal of Biotechnology. 2009;8(15):3502-5.

Deniz I. Kizilcam (Pinus brutia Ten.) Reçinesinin Kimyasal Özellikleri [tez]. Karadeniz Trabzon: Teknik Üniversitesi; 1987.

Gether L, Gyldenlove M, Thyssen J. Christmas tree dermatitis casued by colophonium allergy. Contact Dermatitis. 2017;77:406-29.

Goren AC, Bilsel G, Ozturk A, Topcu G. Chemical composition of natural colophony from Pinus brutia and comparison with synthetic colophony. Natural Product Communications. 2010;5(11):1729-32.

Hafizoglu H, Deniz I. Orman Urünleri Kimyasi Ders Notu (Forest Products Chemistry) KTU Trabzon: 2010. 201p.

Hofer R. The pine biorefinery platform chemicals value chain. In: Pandey A, Hofer R, Taherzadeh M, Nampoothiri M, Larroche C. Industrial biorefineries and white biotechnology. London: Elsevier; 2015. p.127-55.

Karlberg AT. Colophony. In: Kanerva L, Wahlberg JE, Elsner P, Maibach HI. Handbook of occupational dermatology. Berlin: Springer-Verlag; 2000. p.509-16.

Karlberg AT. Colophony: rosin in unmodified and modified form. In: Rustemeyer T, Elsner P, John 
SM, Maibach HI. Kanerva's occupational dermatology. $2^{\text {nd }}$.ed. Berlin: Springer-Verlag; 2012. v. 1 p.467-79.

Kilic A, Hafizoglu H, Donmez IE, Tumen I, Sivrikaya H, Hemming J, Reunanen M. Liphophillic constituents of some coniferous cones. Journal of Bartin Faculty of Forestry. 2013;15(1):122-7.

Kilic A, Hafizoglu H, Tumen I, Donmez IE, Sivrikaya H, Hemming J. Phenolic extractives of cones and berries from Turkish confireous species. European Journal of Wood and Wood Products. 2011;69:63-6.

Kim JH, Min HJ, Park K, Kim J. Preparation and evaluation of cosmetic adhesive containing guar gum. Korean Journal of Chemical Engineering. 2017;24(8):2236-40.

Nilsson U, Karlberg AT, Lassen P. Development of an analysis method for quantification of colophonium component in cosmetic products. Denmark: Danish Ministry of the Environment, Environmental Protection Agency; 2009.

Nuttens N, Verboekend D, Deneyer A, Van Aelst J, Sels BF. Potential of sustainable hierarchical zeolites in the valorization of á-pinene. ChemSusChem. 2015;8(7):1197-205.

Rodrigues-Corrêa KC, Lima JC, Fett-Neto AG. Oleoresin from Pine: Production and industrail uses. In: Ramawat KG, Merillon JM. editors. Natural products. Berlin: Springer-Verlag; 2013.p.4038-51.

Rogachev A, Salakhutdinov NF. Chemical composition of pinus sibirica (Pinacea). Chemistry\&Biodiversity. 2015;12(1):1-53.
Satil F, Selvi S, Polat R. Ethnic uses of pine resin production from Pinus brutia by native people on the Kazdað Mountain (Mt. Ida) in Western Turkey. Journal of Food

Agriculture\&Environment. 2011;9(3-4):1059-63.

Serin Odabas Z, Deniz I, Kilic M. Importance and situation of resin in the world. In: $3^{\text {rd }}$ Non-Wood Forest Products Symposium, 8-10 May, kahramanmaras-Turkey; 2014. p.584-91.

Silvestre AJD, Gandini A. Terpenes: Major sources, properties and applications. In: Belgacem MN, Gandini A. Monomers, polymers and composites from renewable resources. Amsterdam: Elsevier; 2008. p.17-38.

Spinella A, Malagodi M, Saladino ML, Weththimuni ML, Caponetti E, Licchelli M. Astep forward in disclosing the secret of stradivari's varnish by NMR spectroscopy. Journal of Polymer Science, Part A: Polymer Chemistry. 2017;55:3949-54.

Tumen I, Akkol Kupeli E, Sunter I, Keles H. Wound repair and anti-inflammatory potential of essential oils from cones of Pineceae: Preclinical experimental research in animal models. Journal of Ethnopharmacology. 2011;137(3):1215-20.

Yadav BK, Gidwani B, Yas A. Rosin: Recent advances and potential applications in novel drug delivery system. Journal of Bioactive and Compatible Polymers. 2016;31(2):111-26.

Yavaser R, Erkus H, Sunna C, Karagozler AA. Evaluation of antioxidant and antimicrobial activity of Abies Cilicica (Ant\&Kotschy) subs:isaurica coodle\&Cullen resi( ). European Journal of Biotechnology and Bioscience. 2015;3(10):37-44. 